\title{
What School Counselors Say: Training Needs for Preventing Child Sexual Abuse
}

\author{
Fevziye Dolunay Cuğ ${ }^{1}$ \\ ${ }^{1}$ Educational Sciences, Kocaeli University, Kocaeli, Turkey \\ Correspondence: Department of Educational Sciences, Kocaeli University, Umuttepe Campus, Kocaeli, Turkey. \\ Tel: 90-262-303-2509. E-mail: dolunayfevziye@ gmail.com
}

Received: January 9, 2021

doi:10.5539/hes.v12n1p155
Accepted: February 26, 2022 Online Published: February 28, 2022

URL: https://doi.org/10.5539/hes.v12n1p155

\begin{abstract}
The goal of the present study was to understand the current needs of school counselors for preventing child sexual abuse. The need assessment study was carried out with a focus group sample. The participants were school counselors who work in various types of schools. The researcher contacted the school counselors and invited them to participate in the research. During the focus group meetings, the researcher collected the data through audio recordings and later transcribed them. Content analysis was used to generate codes, and codes were grouped into subthemes, which were used to identify themes. Focus group data were categorized according to three themes: 1) the perceptions of school counselors' role in preventing abuse; 2) the issues that school counselors' feelings of inadequacy in preventing abuse, and 3) the recommendations for the future prevention programs. Based on the results of the study, school counselors had limited theoretical knowledge and professional competence regarding child sexual abuse. The results also revealed that some prevention programs in Turkey were available but insufficient to meet the needs of school counselors. Moreover, the researcher discussed implications for future research and practice were discussed.
\end{abstract}

Keywords: child sexual abuse, school counselors, needs assessment

\section{Introduction}

Child sexual abuse is among the most common types of child maltreatment after neglect and physical abuse (Tiraş, Dilli, Dallar, \& Oral, 2009). As stated by several researchers (Lampe, 2002; Çeçen, 2007; Russella, Higginsa, \& Possob, 2020), child sexual abuse is a complicated and critical issue across the world. The definition of child sexual abuse is "when an older child, a youth, or an adult uses a child for his or her own sexual gratification" (Child Abuse Prevention and Treatment Act [CAPTA], 2019). Sexual abuse can be in two forms: (1) direct sexual contact, such as touching a child's breasts or genitals or having sexual or oral intercourse, and (2) indirect behaviors, such as exposing a child to inappropriate sexual content (Mathews \& Collin-Vezina, 2017). According to recent statistics, $26.6 \%$ of girls and $5.1 \%$ of boys are exposed to sexual abuse (Finkelhor, Shattuck, Turner, \& Hamby, 2014). Child abuse may have serious psychosocial and physical consequences that negatively affect health of the abused child. Although the physical and psychological consequences of child sexual abuse might heal with time, the medical and psychological effects can last through adulthood (Johnson, 2004). Moreover, the effect of child abuse can be long-term as well as short-term. Finkelhor (1990) underlined that stress-related effects such as sleep difficulties, anxieties, and distractedness can occur in children. As a long-term effect, adults may have marital problems, less sexual satisfaction, and lower levels of religiosity. Besides, the lockdowns due to COVID-19 for families and many children who are already living in difficult conditions increase the likelihood of sexual maltreatment and limit access to supportive services (Collin-Vezina, Brend, \& Beeman, 2020).

Child abuse prevention programs gained importance in western countries around the early 1970s (Kohl, 1993). The literature on the prevention of CAN refers to a three-stage process, namely primary, secondary, and tertiary prevention (Wurtele \& Kenny, 2010). Primary prevention involves informing the community, the family, and the child before violence against the child takes place. Secondary prevention requires working with high-risk groups in terms of abuse or neglect in the community. Tertiary prevention involves studies to reduce the potential effects of violence after abuse or neglect and to prevent from violence occurring again. Schools are essential sources to implement primary and secondary prevention programs since children are always available in the schools (Shaw, 
1986). According to a review by Barron and Topping (2008) on the effectiveness of 22 school-based child sexual abuse prevention programs between 1990 and 2002, the best practices of prevention programs were the ones that aimed to increase the children's awareness and to teach self-protective skills. Furthermore, in these programs, knowledge, skills, emotion, risk perception, touch discrimination, reported reaction to real threat/abuse, disclosure, negative impacts, and maintenance of gains concerns were given priority. For example, assisting children to recognize forms of abuse; teaching children to say "no" or avoid undesirable touches; encouraging children to tell a trusted adult; reassuring children that this is not their fault; distinguishing between $\mathrm{good} / \mathrm{bad}$ touch and good/bad secrets; and developing strategies to eliminate the risk of abuse. Russella, Higgins, and Posso (2020) also examined the effectiveness of eight school-based child sexual abuse prevention programs in developing countries. According to this review study, prevention programs aimed to increase the children's awareness and to teach self-protective skills. Furthermore, knowledge, skills, emotion, perception of risk, touch discrimination, reported response to actual threat/abuse, disclosure, negative effects, and maintenance of gains issues were considered on a preferential basis in these programs. Most of the interventions evaluated empirically in developing countries have focused on children of preschool and primary school age (Russella Higgins, \& Posso, 2020).

Children are not aware of sexual abuse or self-protection skills (Kenny, Capri, Thakkar-Kolar, Ryan, \& Runyan 2008). Being aware of abuse-response skills may decrease the abusive behaviors when they are exposed. Therefore, prevention programs may have an essential role to enhance children's awareness (Kenny, Capri, Thakkar-Kolar, Ryan, \& Runyan, 2008). Sexual abuse prevention programs should be applied through school-based education programs (Russella, Higgins, \& Posso, 2020). The researches show that the benefits of prevention programs increase the personal safety skills of children and their knowledge about sexual abuse (Çıtak-Tunç et al., 2018), and child abuse disclosures (Walsh, Zwi, Woolfenden, \& Shlonsky, 2015).

School counselors have a critical role in intervening, treating, and preventing child sexual abuse in schools (Goldman \& Padayachi, 2005). The task of dealing with this issue is one of the responsibilities of school counselors because their roles are multiple such as consultant, advocate, mediator, identifiers. As a consultant, the school counselor provides information to educate the teachers and school administrators. In the advocate role, the school counselor defends students' rights in implementing discipline procedures and has a responsibility to provide assistance, support, and training students in abuse events. As a mediator, the school counselor figures out some disagreements and misunderstandings between teachers and students or parents. Lastly, as an identifier, the school counselor should recognize the evidence of the abuse (McEachern, Aluede, \& Kenny, 2008).

School counselors having ethical and legal reporting obligations should be well-versed in the signs and symptoms of child sexual abuse, as well as the short and long-term consequences, and the establishment of preventive and treatment programs (Miller, Dove, \& Miller, 2007; Siviş-Çetinkaya, 2015). However, school counselors may feel unqualified to detect sexual abuse and lack the counseling skills necessary to intervene in sexually abused children (Goldman \& Padayachi, 2005; Harris \& Jeffery, 2010). Therefore, the training programs for school counselors are necessary for increasing their professional efficacy (Goldman \& Padayachi, 2005).

According to Siviş-Çetinkaya (2015), reporting child sexual abuse in the school context may demand a well-informed and cooperative school staff to coordinate the procedure. This research showed that teachers and principals seem more unwilling and less knowledgeable on reporting than school counselors. As a result, skilled school counselors may play a critical role in teacher, administrator, and other staff training (Cowan, Cole, \& Craigen, 2019). The professional school counselor should help to prepare a protocol in advance about what to do when a case of sexual abuse occurs and ensure that this protocol is followed. In addition, professional school counselors should provide teachers and school administrators with educational resources on recognizing signs of abuse (Sikes, 2008).

In Turkey, few studies that represent the prevalence of sexual abuse. One of them is conducted in Istanbul among female high school students (Alikaşifoğlu et al., 2006). According to this study, 250 (13.4\%) of 1955 female high school students were sexually abused. Moreover, $1.8 \%$ of them reported the incest relationship. While 91 (4.9\%) of female students declared to be forced to have sexual intercourse, $213(11.3 \%)$ of them declared someone touched their private body parts in a way they did not like. In other studies, 50 cases diagnosed in five teaching hospitals were presented (Oral et al., 2001). While 60\% of them were physically abused, $26 \%$ of them were sexually abused, and while $18 \%$ of them were emotionally abused, $20 \%$ of them were severely neglected. In the recent statistics, it is seen that $15.2 \%$ of 206 thousand 498 children who came to the police departments as victims of crime in 2019 were due to sexual crimes (Turkish Statistical Institute [TSI], 2020). While the number of crimes in cases filed on the subject of sexual abuse of children in Criminal Courts in Turkey was 17 thousand 
589 in 2012, it increased to 22 thousand 689 in 2019 (General Directorate of Criminal Records and Statistics [GDCRS], 2019). The comprehensive statistical data of the child abuse cases are not still available because of a lack of reporting. It can make it difficult to reach the prevalence of child abuse except diagnosing cases.

In Turkey, Demircioğlu and Işı (2019) examined developed school-based programs and their effectiveness. Based on the study, although there have been implemented basic prevention programs under The National Education Ministry, these are not just related to sexual abuse. These programs include other types of prevention topics such as drug, alcohol, bad habits, and sexual education. Besides, prevention programs have been also utilized in some non-governmental organizations. There are studies conducted by various institutions and organizations at different levels of education for the prevention of sexual abuse in Turkey, but there is no standard prevention program developed to prevent abuse.

As above mentioned, school counselors have a convenient position providing valuable assistance to prevent sexual abuse and to intervene to sexually abused children. However, school counselors have limited theoretical knowledge and professional competence on abuse and there is a lack of knowledge about how to work with the abused child (Uçar, Yıldız, Dursun-Bilgin, \& Baştemur, 2020). The existing studies in the literature provide descriptive information about sexual abuse of children but there is no comprehensive psycho-education practice to prevent sexual abuse with proven effectiveness in Turkey. In the light of the information in the literature, it is aimed to meet this need in the field of practice with a new psycho-education program to prevent sexual abuse. Applying the needs analysis for program development throughout Turkey will ensure that the program is prepared in a way that will meet the needs of not only psychological counselors with certain characteristics. As a result, the present study aims to conduct a needs assessment and offer a psycho-educational program to increase school counselors' knowledge, abilities, and hence self-efficacy in the area of child sexual abuse. This study focuses specifically on sexual abuse because child sexual abuse is a case that professionals are afraid to confront and do not know how to intervene.

\section{Method}

\subsection{Research Design}

This study adopts a phenomenological perspective for examining the needs of school counselors in a qualitative inquiry. The qualitative approach necessitates a holistic view of the phenomena; the researcher tries to understand the "meaning" by inductively (Bogdan \& Biklen, 2007). Therefore, semi-structured focus groups were carried out with school counselors to obtain information about their perception, experiences, and training needs on child sexual abuse. The research was conducted in the capital city in Turkey and counselors working at different educational levels were determined as the population group.

\subsection{Participants and Sampling}

The heterogeneous sample sampling technique, which is a type of purposive sampling, represents maximum variation (Patton, 2002). Therefore, the researcher contacted one of the largest countries' Guidance and Research Center [GRC] to reach the target population. Firstly, necessary permissions and a list of school counselors in school were taken from the GRC. The researcher connected with these school counselors and gathered information via the request form including their education, their gender, their volunteering, and students' profile in the school. School counselors approved the focus group was chosen..

The school counselors, who constituted the sample of the study, were selected from the region where the students from low socio-economic levels were located. The participants were composed of 28 school counselors who work in different types of schools; elementary school, high school, private school, special school (for disabled children) in Ankara. The sample consisted of 25 females and 3 males. The ratio of the female participants was high since most of the school counselors are female. Fifteen of them were graduated from the psychological counseling and guidance program; nine of them were graduated from a related education program, and five of them graduate from the psychology program. Four of them have a master's degree. While 23 participants had previously received training on child abuse, 5 participants did not receive any training.

\subsection{Data Collection Tool}

First, a detailed literature review about the study was conducted. After this literature review, a conceptual draft was created and interview questions and demographic questions were prepared by the researcher. To conduct the focus groups, the questions were formed with the semi-structured interview technique (Patton, 2002). The questions were finalized as a result of the consensus made with a researcher who is an expert in the field of qualitative analysis and the examination of an expert in the field of school counseling. The first part of the interview form consisted of demographic questions. Demographic Form developed to gather information related 
to gender, age, and school counselors' work setting prior knowledge/experience and educational background. Their demographic information was used for sample description and interpretation of the result. The second part of the form consisted of questions to understand the needs of the participants. The first question was to understand their perception of their role to prevent child sexual abuse. Other questions of the focus groups were related to the issues that counselors felt inadequate to prevent abuse. Finally, they were asked, "How prevention programs should be?" Focus groups continued until the ideas were saturated.

\subsection{Data Collection Procedure}

In the first step of this study, the permission of the Human Subjects Ethics Committee at METU (Middle East Technical University) was obtained. Secondly, necessary permissions and a list of school counselors in school were taken from MEB (The Ministry of Education). According to the list, clusters were determined and school counselors were chosen randomly. School counselors were invited to participate in the study and the researcher gave information about the study. School counselors who approved the training were assigned randomly to three focus groups. It was regarded to have school counselors working at different education levels in each group. Then, the need assessment study was carried out on the planned time and place. Focus groups were held in a room suitable for group work in the Guidance and Research Center, with a researcher and participants in a single session. The researcher was qualified in qualitative studies and focus groups during her higher education. The ethics committee was approved at both institutions and all participants signed informed consent before participation

The participants were informed that the moderator's role is to ask questions to get the conversation started and to keep the emphasis on the issue, but not to join in it. Each debate lasted around 90 minutes and was entirely among the participants. The focus group procedure addressed three important questions after the introductions: (1) What are your thoughts about child sexual abuse you have experienced in the school? (2) Which topics do you feel inadequate when they encountered child sexual abuse? (3) What do you do to prevent child sexual abuse? The moderator summarized the remarks and moved on to the next topic when each question's discussion was completed. All process of the focus group was audio-recorded with the consent of the participants.

\subsection{Data Analysis}

For a needs assessment, records of the focus groups were transcribed by the researcher. Content analysis was used to generate codes. In this approach, the researcher develops a coding system after the data is collected, i.e. there is no existing framework for the coding (Marshall \& Rossman, 2006) Focus group information was transcribed as free text and evaluated as a single data set into a single codebook. First, two experts in qualitative analysis separately analyzed the deciphered interview text according to recurring ideas and themes. Later, two researchers came together and cross-checked their codes and a code list was created. In cases of conflict, the codes were discussed and an external auditor's opinion on the common code list was sought to ensure validity and reliability. Data were coded by more than one researcher to ensure validity and reliability. When the coding was completed, themes were determined as being consistent with the codes. Finally, the codes were divided into categories, and themes were created from these categories in consideration of the research questions. Some of the answers given by the school counselors during the focus groups were given in the findings section through direct quotations.

\subsection{Trustworthiness}

Lincoln and Guba (1985) describe four criteria for ensuring trustworthiness in a qualitative approach: a) Credibility (internal validity), b) Transferability (external validity/generalizability), c) Dependability (reliability) and d) Confirmability (objectivity). There are different procedures for checking and enhancing trustworthiness. The sources of trustworthiness for the present study are coming from different practices.

In the coding process, two researchers studied the notes inter-changeably to meet internal validity. In addition, expert opinion was asked at each step of the study. That is, generating interview questions and concluding the results were reviewed by an expert audit. This met the dependability of the study since techniques used in this study were evaluated to provide credibility and transferability criteria (Lincoln \& Guba, 1985).

Furthermore, recording the focus groups was suggested as a way of ensuring trustworthiness (Yıldırım \& Şimşek, 2008). In this study, all the focus groups were audio-recorded and it increased the strength of the study because all information given by the participant was available to the researcher.

\subsection{Limitation of the Research}

As well as its strengths, the present study has some limitations. One of these limitations is that researcher characteristics might have a role in the quality of the obtained data. It might affect the interpretation of the 
findings. Another limitation of the study is related to the assumptions of the qualitative paradigm. In qualitative research, the aim is to detect the phenomena in a holistic view, but, in the present study, only one source of data that is school counselors will be considered. Further research might be recruited different sources of data such as family members, children, and school staff. As a recommendation for improving the methodology of future studies, through recruiting different sources of data, the trustworthiness of the study can be enhanced. In addition, unlike the research studies based on a quantitative paradigm, qualitative design studies do not have a concern to generalize the results to the population (Yin, 2009). Therefore, specific sample characteristics and their effect on the lack of generalizability of the findings is not a limitation but one of the characteristics of the paradigm of study. Lastly, the study included one district. Therefore, the representation of school counselors in the focus group was narrow in scope. In order to strengthen the trustworthiness of the study, member check and triangulation of data sources and triangulation of data analysis techniques that are not available in the present study can be achieved.

\section{Results}

Focus groups' results were categorized under three themes: 1) The perceptions of school counselors' role in preventing abuse, 2) The issues that school counselors feel inadequate to prevent abuse, 3) Recommendations for the design of future prevention programs. Below, the data related to each theme were analyzed separately. In Figure 1, three themes and their subthemes were represented below.

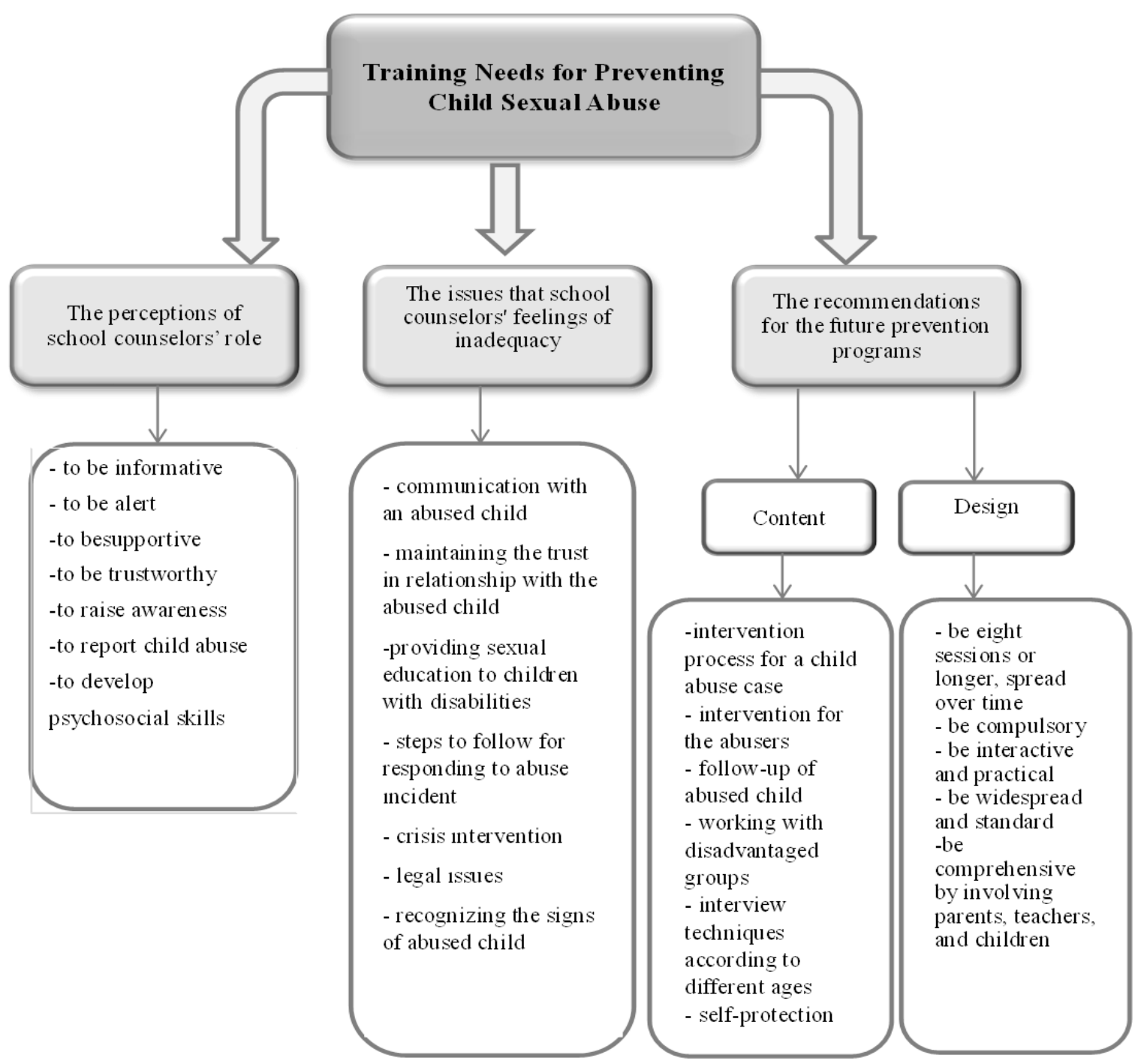

Figure 1. The themes and subthemes in the present study 


\subsection{Theme 1: The Perceptions of School Counselors' Role in Preventing Abuse}

School counselors evaluated both their own and their colleagues' roles in preventing child abuse. In this context, this theme was divided into seven subthemes, these subthemes and their quotations were represented respectively;

\subsubsection{To Be Informative}

"We should regularly inform children about protecting their bodies and saying no. We can also inform the teachers about the signs of abuse and that they should report it to the guidance service since they are always with the children in the classroom."

\subsubsection{To Be on the Alert about Abused Children}

"The student in primary education cannot say this anyway. Whether the mother understands or someone sees it, this case emerges that way. Therefore, it is very important to observe the child."

\subsubsection{To Be Supportive}

"...and if they have experienced such a thing, we can give the message that I am your supporter, you are not guilty."

\subsubsection{To Be Trustworthy}

"...In addition to these, the role of the school counselor is to create a sense of trust. In other words, the child needs to be able to trust him and tell him, and I think this is the most important factor."

\subsubsection{To Raise Awareness}

"It is necessary to be able to teach children to touch badly and to touch well and to teach the difference between them to families, too. It is necessary to raise awareness about abuse because sometimes neither families nor children know that it is abuse."

\subsubsection{To Report Child Abuse}

"The abuse must be reported. The school administration should also be told that it is what needs to be done; otherwise, it is a crime."

\subsubsection{To Develop Psychosocial Skills}

"We should carry out activities that improve children's ability to know themselves, express their feelings, understand the feelings of others, recognize their bodies, and distinguish abuse."

\subsection{Theme 2: The Issues that School Counselor' Feelings of Inadequacy in Preventing Abuse}

Participants were asked to describe the issues that they feel inadequate while working with child abuse. This theme comprised seven subthemes. These subthemes and their quotations were represented below:

\subsubsection{Communication with an Abused Child}

"The painting technique is mostly used to express the feelings of young children about the case. Therefore, I would like to have skills of this technique, if they have to talk to us directly - which is mostly the case, then I think I need additional skills on how to communicate with the child."

3.2.2 Maintaining the Trust in Relationship with the Abused Child

“...Suppose that, they reported it to us and they did not want anyone to hear it. Their father did not know, their mother did not know, but their mother was told later. You lose their trust the moment you said it. We don't know how to say it without losing their trust."

3.2.3 Providing Sexual Education to Children with Disabilities

"I have a lot of trouble with mentally handicapped and disabled children because there is no source, there is no proper study done in Turkey and they are unfortunately at risk. Sex education is not done even to normal people or they do not participate, but it is even more difficult for the disabled, at least the other child understands what you are saying, you can contact them somehow, but it is very difficult for me, so this is an area that I need a lot."

3.2.4 Steps to Follow for Responding to Abuse Incident

“... for example, how do we explain it to the parents when we learn it? In one case, our male assistant principal told the parents that such an event happened because he was a male. How can I talk to the parent in that situation? It was a lack. We said to the student, 'We need to inform your family about this, but is this 
a correct method or how can we talk to the child about this? This was a lack. We did not know that he should not speak without a lawyer. We did not know if we should give this to the court or not."

3.2.5 Crisis Intervention

"When I first hear it, I have a hard time controlling my emotions and what to ask in a crisis."

3.2.6 Legal Issues

"When we reveal the abuse, negative things happen, we have no protection, and some people come to school with a knife. Even if you file a criminal complaint, we are legally obliged and yes, we should report, but who will protect us? These are question marks in our minds."

\subsubsection{Recognizing the Signs of Abused Child}

"As it was said at the beginning, which questions will we ask when meeting with the child. Yes, the child is withdrawn, he comes because of a problem, but sometimes it may or may not be related to abuse. I think that the skills of asking questions to recognize abuse should be better taught to us."

\subsection{Theme 3: Recommendations for the Future Prevention Programs}

Participants were asked what makes these prevention programs more effective, the answers given by the participants about the content, design, and content prepared for different groups were grouped under two sub-themes:

3.3.1 Content of Prevention Program - Programs should Teach

-intervention process for a child abuse case

"...In this case, do we need to report, if so, how should we do it? ... We need to know what can be done for the student who said she was abused by her stepfather but changed her statement the next day as "I was jealous of my parents, I wanted their divorce that's why I told her something like that."

-intervention for the abusers

"Sometimes the person who is sexually harassed can be our student, the abuser can be our student, and I would like to learn about how we will approach the abuser."

-follow-up of an abused child

"How should the abused child be approached if he/she attends school? .... We don't get much chance to do long-term consultations, so what should we do?"

-working with disadvantaged groups

"I have a lot of trouble with inclusion students, such as mentally handicapped and disabled children, because there is no source, there is no honest study done in Turkey, and they are unfortunately at risk. They find it even more difficult for sexual education ... at least the other child understands what you are saying, you can reach them somehow, but it is very difficult for me to explain to those children, it is an area that I need a lot."

-interview techniques according to age groups

"If there are different interview techniques according to age groups, they can be included. What other methods can we use instead of asking questions, playing games, taking pictures, in this sense; maybe it would be nice if this support was offered."

-self-protection

"There may be situations where there are many things about sexual abuse that we cannot handle. When we go into details, these are; how we will protect ourselves, how we will react, how we will be less affected, how we will benefit that child, how we will behave like a true expert person."

3.3.2 Design of Prevention Program - The Program should:

-be eight sessions or longer, spread over time.

"If there are more process-based programs that we can apply to the student such as 7-8 weeks, I think we can do this."

-be compulsory

"It should be compulsory for all counselors to attend this training." 
-be interactive and practical

"Theoretically, yes, we know, what child abuse is and what to do, but it would be more instructive to explain it in practice. Meetings should be interactive and practical."

-be widespread and standard

"In other words, if such a program were to be implemented, it would be beneficial to start from pre-school. Guidance programs should be given to these children gradually according to each grade level as a part of life."

-be comprehensive by involving parents, teachers, and children

"I think it can involve teachers, children, and parents simultaneously. For example, such a program can be developed for all of them, not separately."

\section{Discussion}

The current study intended to provide a training needs assessment of school counselors and recommend a design for a psycho-educational program aimed at improving school counselors' knowledge, abilities, and, as a result, self-efficacy in dealing with child sexual abuse. The findings of the study on the experiences of working with child abuse of school psychological counselors were firstly gathered under the theme of the roles of prevention of sexual abuse. The roles of all school counselors participating in the study for preventing child abuse were analyzed; it was found that they were aware of their role and their responsibilities, but they had difficulties in fulfilling the requirements of these roles. The related literature also showed that school psychological counselors play a major role in revealing sexual abuse (Goldman \& Padayachi, 2005). In parallel with the result, the school counselors also should recognize signs and report cases of abuse (Minard, 1993). Psycho-educational programs can help to appropriately manage child abuse and prepare school personnel. To achieve this, school counselors should become more responsible for preventive and awareness programs for educators, children, and their families (Wilder, 1991). For example, one way is to present more information to the students about body safety. Students need to know their rights and need to understand how to ask a professional for help when they are abused.

In the second theme, school counselors identified issues regarding child abuse that they felt inadequate. The findings revealed that although school counselors had some training in preservice education, they could not know how to intervene in the child abuse case. Similar findings have been observed in other related studies, for example, Goldman and Padayachi (2005) reported that most school counselors were unfamiliar with the signs of child abuse cases and lack of counseling skills and procedures for working with sexual abuse. In addition, school counselors in Turkey generally do not think of having professional competence in abuse, and it has been found that there are differences in the experiences of the counselors who have worked with abuse before and their perspectives on the subject (Uçar, Yıldız, Dursun-Bilgin, \& Baştemur, 2020).

School counselors are legally required to report cases of child sexual abuse. Therefore, this necessity causes many school counselors to encounter various problems and experience anxiety. In particular, there are questions and confusions such as to whom/where the suspected case of abuse will be reported, if the suspected case is not true, whether it will be a liar in the legal process, what is the private information that needs to be reported, and what can be done (Lambie, 2005). These results make it necessary to identify their needs when working with child abuse. When such a legal obligation is in question, it is seen that it is crucial for school counselors to receive more effective and comprehensive training on child abuse.

The third theme of the research is related to the content and design of the prevention program to be established. In addition to general information, the participants emphasized that it is important to inform about the process of intervention to the case, intervention to the abuser, follow-up of the abuse victims, working with disadvantaged groups, interview techniques for different age groups, and to protect themselves legally. In addition, it has been emphasized that the programs to be implemented will be more effective if they start at an early age, spread over time, are compulsory, cover many different groups related to abuse, and are interactive and practical. In the literature, it is recommended that school-based programs go beyond providing information and that a prevention framework should be established for wider and wider groups (Russella, Higgins, \& Posso, 2020). In addition, it is pointed out in the international literature that preventive studies should start from kindergarten (McRae, 2016). Wurtele and Kenny (2010) found that instead of long sessions in the preventive program, repeating short sessions more frequently, placing these sessions in a long process was more effective, and they stated that the involvement of the family in the process kept the child safer. Brassard and Fiorvanti (2015), who examined school-based abuse prevention programs, found that these programs were useful in increasing students' 
knowledge and protective behaviors. In addition, for the effectiveness of these programs to continue; it was recommended that the school staff update the information every year, ensure parent participation (parent seminar, homework, newsletter, etc.), and make regular evaluations about the program.

\section{Conclusion}

As a result, school counselors frequently encounter child abuse cases at school and perceive professional inadequacies in matters such as intervention, following legal situations, and self-protection. For this, they need the existence of comprehensive, sustainable, and practical preventive programs both during their university education and in their professional lives. The literature and statistical data showed that cases of child abuse were more common and affected the mental health of the community. This situation highlighted the need for expert groups working with children and their families to be better equipped and the laws to be protective. It is recommended to raise awareness of children, families, and school staff through the school, to develop programs through the Ministry of National Education, and to carry out more intensive studies for regions with high risk.

It is also very important to raise awareness of teachers, which is an important pillar of preventive studies. Doğan and Bayar (2018) reported in their study that while the number of universities that had courses on child abuse among 26 education faculties was 8 , the number of universities that did not have courses on the subject was 18 in Turkey. The number of universities that have courses on child abuse during the education of teacher candidates is very low. On the other hand, teachers in Turkey do not need to take courses on child abuse and neglect during the undergraduate period. Elimination of this educational deficiency is also possible with child abuse prevention training that school psychological counselors will apply to teachers. The reason is that before the psychological counselor, either the child gives information to the teacher he/she trusted about the abuse, or the teachers can better notice the signs of abuse in the classroom.

\section{Conflict of Interest}

I have no conflict of interest to declare.

\section{Funding}

This research did not receive any specific grant from funding agencies in the public, commercial, or not-for-profit sectors.

\section{References}

Alikaşifoğlu, M., Erginöz, E., Ercan, O., Albayrak-Kaymak, D., Uysal, O., \& İlter, O. (2006). Sexual abuse among female high school students in İstanbul, Turkey, Child Abuse \& Neglect, 30(3), 247-255. https://doi.org/10.1016/j.chiabu.2005.10.012

Barron, I., \& Topping, K. (2008). School-based child sexual abuse prevention programs: The evidence on effectiveness, Journal of Children's Services, 3(3), 31-53. https://doi.org/10.1108/17466660200800017

Brassard, M. R., \& Fiorvanti, C. M. (2015). School-based child abuse prevention programs. Psychology in the Schools, 52(1), 40-50. https://doi.org/10.1002/pits.21811

Çeçen, A. R. (2007). Çocuk cinsel istismari: Sıklı̆̆ı, etkileri ve okul temelli önleme yolları. Uluslararası İnsan Bilimleri Dergisi, 1(4), 1-17. Retrieved from https://core.ac.uk/download/pdf/268072105.pdf

Child Abuse Prevention, and Treatment Act [CAPTA]. (2019). What is the child abuse and neglect. Recognizing the signs and symptoms. Retrieved from https://www.childwelfare.gov/pubPDFs/whatiscan.pdf

Çıtak-Tunç, G., Gorak, G., Özyazıcıoğlu, N., Ak, B., Öç, I., \& Vural, P. (2018). Preventing child sexual abuse: Body safety training for young children in Turkey, Journal of Child Sexual Abuse, 27(4), 347-364. https://doi.org/10.1080/10538712.2018.1477001

Collin-V'ezina, D., Brend, D., \& Beeman, I. (2020). When it counts the most: Trauma-informed care and the COVID-19 global pandemic. Developmental Child Welfare, 2(3), 172-179. https://doi.org/10.1177/2516103220942530

Cowan, R. G., Cole, R. F., \& Craigen, L. (2019). School-based child sexual abuse prevention: Implications for professional school counselors. The Professional Counselor, 9(3), 200-210. https://doi.org/10.15241/rc.9.3.200

Demircioğlu, H., \& Işık, E. (2019). Çocuk cinsel istismarını önlemeye yönelik geliştirilen okul temelli programlar ve etkililikleri. Hacettepe Üniversitesi Sosyal Bilimler Dergisi, 1(1), 32-51. Retrieved from https://dergipark.org.tr/tr/pub/husbdergi/issue/48418/585861 
Doğan, T., \& Bayar, Ö. (2018). Çocuk cinsel istismarı: geleceğin öğretmenleri ve okul psikolojik danışmanları ne kadar biliyor? Uluslararası Sosyal Araștırmalar Dergisi, 11(55), 571-581. https://doi.org/10.17719/jisr.20185537230

Finkelhor, D. (1990). Early and long-term effects of child sexual abuse: An update. Professional Psychology, 21(5), 325-330. https://doi.org/10.1037/0735-7028.21.5.325

Finkelhor, D., Shattuck, A., Turner, H. A., \& Hamby, S. L. (2014). The lifetime prevalence of child sexual abuse and sexual assault assessed in late adolescence. Journal of Adolescent Health, 55(3), 329-333. https://doi.org/10.1016/j.jadohealth.2013.12.026

General Directorate of Criminal Records and Statistics [GDCRS]. (2019). Retrieved from Https://Adlisicil.Adalet.Gov.Tr/Resimler/Sayfadokuman/1062020170359hizmeteozel-2019-Bask\%C4\%B1$\%$ C4\%B0SA.Pdf

Goldman J. D., \& Padayachi, U. K. (2005). Child sexual abuse reporting behaviour by school counselors and their for further education. Health Education Journal, 64(4), 302-322. https://doi.org/10.1177/001789690506400403

Harris, G. E., \& Jeffery, G. (2010). School counselors' perceptions on working with student high-risk behaviour. Canadian Journal of Counselling, 44(2), 150-190. Retrieved from https://dev.journalhosting.ucalgary.ca/index.php/rcc/article/view/58911

Johnson, C. F. (2004). Child sexual abuse. The Lancet, 364(9432), 462-470. https://doi.org/10.1016/S0140-6736(04)16771-8

Kenny, M. C., Capri, V., Thakkar-Kolar, R. R., Ryan, E. E., \& Runyan, M. K. (2008). Child sexual abuse: From prevention to self-protection. Child Abuse Review, 17, 36-54. https://doi.org/10.1002/car.1012

Kohl, J. (1993). School-based child sexual abuse prevention programs. Journal of Family Violence, 8(2), 137-150. https://doi.org/10.1007/BF00981764

Lambie, G. W. (2005). Child abuse and neglect: A practical guide for professional school counselors. Professional School Counseling, 8(3), 249-258. Retrieved from https://www.jstor.org/stable/pdf/42732466.pdf

Lampe A. (2002). The prevalence of childhood sexual abuse, physical abuse and emotional neglect in Europe. Psychosomatic Med Psychotherapy, 48(4), 370-80. https://doi.org/10.13109/zptm.2002.48.4.370

Lincoln, Y. S., \& Guba, E. G. (1985). Naturalistic inquiry. Beverly Hills, CA: Sage. https://doi.org/10.1016/0147-1767(85)90062-8

Marshall, C., \& Rossman, G. B. (2006). Designing qualitative research (3rd ed.). Thousand Oaks, CA: Sage.

Mathews, B., \& Collin-Vezina, D. (2017). Child sexual abuse: Toward a conceptual model and definition. Trauma, Violence \& Abuse, 20(2), 131-148. https://doi.org/10.1177/1524838017738726

McEachern, A. G., Aluede, O., \& Kenny, M. C. (2008). Emotional abuse in the classroom: Implications and interventions for counselors. Journal of Counseling \& Development, 86, 3-10. https://doi.org/10.1002/j.1556-6678.2008.tb00619.x

McRae, R. A. (2016). Child Abuse: Signs, Symptoms, and the Role of the School Counselor. Counselor Education Capstones, 52. Retrieved from https://openriver.winona.edu/counseloreducationcapstones/52

Miller, K. L., Dove, M. K., \& Miller, S. M. (2007, October). A counselor's guide to child sexual abuse: Prevention, reporting, and treatment strategies. Paper based on a program presented at the 2007 Association for Counselor Education and Supervision Conference, Columbus, Ohio. Retrieved from https://www.counseling.org/resources/library/vistas/2009-v-online/miller-dove-miller.pdf

Minard, S. M. (1993). The school counselors' role in confronting child sexual abuse. School Counselor, 41(1), 9-15.

Oral, R., Can, D., Kaplan, S., Polat, S., Ateş, N., Çetin, G., Miral, S., ... Tiraş, B. (2001). Child abuse in Turkey: An experience in overcoming denial and a description of 50 cases. Child Abuse \& Neglect, 25(2), 279-290. https://doi.org/10.1016/s0145-2134(00)00241-6

Patton, M. Q. (2002). Qualitative evaluation and research methods. Newbury Park, CA: Sage.

Russell, D., Higgins, D., \& Posso, A. (2020). Preventing child sexual abuse: A systematic review of interventions and their efficacy in developing countries. Child Abuse \& Neglect, 102, 104395. 
https://doi.org/10.1016/j.chiabu.2020.104395

Shaw, M. C. (1986). The prevention of learning and interpersonal problems. Journal of Counseling and Development, 64(10), 624-627. https://doi.org/10.1002/j.1556-6676.1986.tb01024.x

Sikes, A. (2008). A school counselor's guide to reporting child abuse and neglect. Journal of School Counseling, 6(25). Retrieved from https://files.eric.ed.gov/fulltext/EJ894796.pdf

Siviş-Çetinkaya, R. (2015). Turkish school counselors' experiences of reporting child sexual abuse: A brief report, Journal of Child Sexual Abuse, 24(8), 908-921. https://doi.org/10.1080/10538712.2015.1084072

Tıraş, U., Dilli, D., Dallar, Y., \& Oral, R. (2009). Evaluation and follow-up of cases diagnosed as child abuse and neglect at a tertiary hospital in Turkey. Turkish Journal of Medical Sciences, 39, 969-977. https://doi.org/10.3906/sag-0805

Uçar, S., Yıldız, Y., Dursun Bilgin, M., \& Baştemur, Ş. (2020). Okul psikolojik danışmanlarının çocuk istismarıyla çalışma yeterliliklerine ilişkin nitel bir araştırma. Hacettepe Üniversitesi Eğitim Fakültesi Dergisi, 35(2), 404-414. https://dx.doi.org/10.16986/HUJE.2018044070

Walsh, K., Zwi, K., Woolfenden, S., \& Shlonsky, A. (2015). School-based education programmes for the prevention of child sexual abuse. Cochrane Database of Systematic Reviews, 4. https://doi.org/10.1002/14651858.CD004380.pub3

Wurtele, S. K., \& Kenny, M. C. (2010). Partnering with parents to prevent childhood sexual abuse. Child Abuse Review, 19(2), 130-152. https://doi.org /10.1002/car.1112

Yin, R. K. (2009). Case study research: Design and methods. Thousand Oaks, CA: Sage.

\section{Copyrights}

Copyright for this article is retained by the author(s), with first publication rights granted to the journal.

This is an open-access article distributed under the terms and conditions of the Creative Commons Attribution license (http://creativecommons.org/licenses/by/4.0/). 